\title{
処方せんよりみた調剤業務旦の統計的考䀂*1
}

\author{
斉藤 弥, 宮 家 淳*2, 岩崎 由雄*3 \\ 東京都済生会中央病院薬骫部*1 \\ 東京大学医学部付属病院分院楽郕部*2
}

\section{Analysis of Number of Prescriptions and Amount of Dispensing Services}

\author{
WATARU SAITO, ATSUSHI MIYAKE*2 and YOSHIO IWASAKI*3 \\ Department of Pharmacy, Tokyo-to Saiseikai Central Hospital*a \\ Department of Pharmacy, Tokyo University Branch Hospital*3
}

\begin{abstract}
In the previous report, seasonal variation in number of prescriptions and amount of dispensing services was analyzed by moving average method. Statistical analysis of the amount of dispensing services is made in the following on regression equation by the method of least inspection. Then, modified seasonal variation was compared with analyzed original data. As a result, the method of analysis of RUN on the basis of the total number of the run separated on the median line proved simple and useful. Change in regression equation was not so different between the original data and modified seasonal variation. Since the interval estimation of the amount of services showed a marked reduction, the modified seasonal variation may be very applicable in prediction. According to the statistical analysis, modified seasonal variation produced better results than original data, data on outpatints than total data, and daily average than monthly total.
\end{abstract}

\section{はじめに}

近年, 病院薬局では処方せんの増加と処方内容の複雑 化により, 調剤業務量の著しい増加が問題になってい る. そこで著者らは病院薬局における調剂業務管理とし

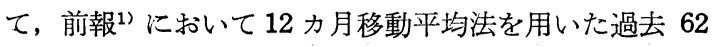
力月間の調剂業務量の推移と, 月別平均法の対傾向值比 率法による季節変動値を用いた月別変動值の変化を報告 した. 今回引続き, 予測を行なら統計的方法として, 最 小 2 乗法を用いた回帰方程式をもとめ各統計学的解析を 行なった. また, 月別変動修正值をもとめて原系列値と 同様の統計学的解析を行ない, 各解析值の比較検討を行 なった。

\section{調 查 方 法}

各数値の算定方法は前報同様 ${ }^{1)}$ である. 1971 年 1 月

*1 本報を調剤業務の管理学的検討（第 2 報）とす る.

*2 東京都港区三田 1 丁目 4-17 ; 4-17, Mita 1-chome, Minato-ku, Tokyo, 108 Japan

*3 東京都文京区目白台 3 丁目 28-6 ; 28-6, Mejirodai 3-chome, Bunkyo-ku, Tokyo, 112 Japan
より 1976 年 2 月まで 62 力月間について, 1 力月外来 処方せん枚数, 1 力月総処方せん枚数, 1 力月外来処方 件数, 1 力月総処方件数, 1 力月外来剂数, 1 力月総剂 数,および暦日変動を除去した 1 日平均外来処方せん枚 数の 7 項目に分けて集計を行ない， 62 力月間を時系列 関数として時間 $\mathrm{t}$ の独立变数 $(\mathrm{xi})$ 処方せん枚数, 処方件 数,および剂数を従属変数 (yi)として統計解析を行なっ た。

統計解析法として, 中央値で分けられる連の総数によ る正規近似 RUN 検定, (I ${ }^{2)}$, 散布図上の水平中央線 で分けられる連の総数による RUN 検定 (II $)^{3)}$ ，相関 係数 $(r)$ の検定 ${ }^{4,6)}$, 相関係数を 2 乘して xi が yi に 影響をおよぼしている度合を示す寄与率 $\left(\mathrm{r}^{2}\right)^{4,5,6)}$, 全 体の標準偏差と回㷌分散による残差偏差 ${ }^{4,6)}$, 各標準偏 差值をとの平均値で除し同じ基準にした変動係数値の比 較5), 最小 2 乗法を用いた回州方程式 $4,5,7,8)$, 回㷌式の 分散分析, 回帰検定 ${ }^{4,6)}$, および各值の $95 \%$ 信頼区間と 回帰式の 95\% 信頼区間の区間推定 ${ }^{4,6)}$ を行なった。ま た, 月別変動修正值は原系列值を月別変動指数で補正し た値とした2). 
表 1-A. 時系列解析による処方せん枚数, 処方件数, おょび凮数に関する RUN の検定, 相関係 数の検定, および変動係数

\begin{tabular}{|c|c|c|c|c|c|c|c|}
\hline 項 目 & $\begin{array}{c}\mathrm{R} U \mathrm{~N}(\mathrm{I}) \\
\mathrm{Z}_{\mathrm{o}}(62,0.05) \\
=-1.64\end{array}$ & \begin{tabular}{c|c|} 
R.U N $($ II $)$ \\
$\mu_{5}(62,0.05)=25$ \\
$\mu_{1}(62,0.01)=22$
\end{tabular} & $\begin{array}{c}\text { 相関係数 } \\
(\mathbf{r})\end{array}$ & $\begin{array}{c}\text { 寄与率 } \\
\left(r^{2}\right)\end{array}$ & $\begin{array}{c}\text { 相関係数検定 } \\
F(1,60 ; 0.01)=7.08\end{array}$ & $\begin{array}{l}\text { 標準偏差 } \\
\mathrm{ST}_{\mathrm{T}} \mathrm{Se}\end{array}$ & $\begin{array}{l}\text { 変動係数 } \\
\mathrm{C}_{\mathrm{I}}=\mathrm{S} / \overline{\mathrm{x}}\end{array}$ \\
\hline $\begin{array}{l}1 \text { 日平均 } \\
\text { 外来処方せん枚数 }\end{array}$ & $\begin{array}{c}\mathrm{Z}=-3.07<\mathrm{Z}_{0} \\
\text { 適合 }(0.05)\end{array}$ & $\begin{array}{c}\mu=20<\mu_{1} \\
\text { 適合 }(1 \%)\end{array}$ & 0.686 & 0.470 & $\begin{array}{l}F_{R}=53.27>F \\
\text { 適合 }(\alpha=0.01)\end{array}$ & $\begin{array}{ll}\mathrm{ST} & 41.59 \\
\mathrm{Se} & 30.52\end{array}$ & $\begin{array}{l}\text { C } 1 \text { T.I } 0.093 \\
\text { Ce.I } 0.068\end{array}$ \\
\hline $\begin{array}{l}1 \text { 力月 } \\
\text { 外来処方せん枚数 }\end{array}$ & $\mid \begin{array}{c}\mathrm{Z}=-4.09<\mathrm{Z}_{0} \\
\text { 適合 }(5 \%)\end{array}$ & $\begin{array}{c}\mu=16<\mu 1 \\
\text { 適合 }(1 \%)\end{array}$ & 0.587 & 0.344 & $\begin{array}{l}F_{R}=31.46>F \\
\text { 適合 }(\alpha=0.01)\end{array}$ & $\begin{array}{lr}\mathrm{S}_{\mathrm{T}} & 1076.3 \\
\mathrm{Se} & 878.8\end{array}$ & $\begin{array}{ll}\text { CT.I }_{\text {T }} & 0.097 \\
\text { Ce.I } & 0.079\end{array}$ \\
\hline $\begin{array}{l}1 \text { 力月 } \\
\text { 総処方せん枚数 }\end{array}$ & $\begin{array}{c}\mathrm{Z}=-1.28>\mathrm{Z}_{0} \\
\text { 不 適 合 }\end{array}$ & $\begin{array}{l}\mu=27>\mu_{5} \\
\text { 不 適 合 }\end{array}$ & 0.441 & 0.195 & $\begin{array}{l}F_{R}=14.23>F \\
\text { 適合 }(\alpha=0.01)\end{array}$ & $\begin{array}{ll}\text { ST } & 1177.5 \\
\text { Se } & 1065.5\end{array}$ & $\begin{array}{ll}\text { CT.I } & 0.084 \\
\text { Ce.I } & 0.076\end{array}$ \\
\hline $\begin{array}{l}1 \text { 力月 } \\
\text { 外来処方件数 }\end{array}$ & $\begin{array}{c}\mathrm{Z}=-4.10<\mathrm{Z}_{0} \\
\text { 適合 }(5 \%)\end{array}$ & $\begin{array}{c}\mu=16<\mu_{1} \\
\text { 適合 }(1 \%)\end{array}$ & 0.700 & 0.491 & $\begin{array}{l}F_{R}=57.88>F \\
\text { 適合 }(\alpha=0.01)\end{array}$ & $\begin{array}{ll}\mathrm{ST}_{\mathrm{T}} & 1706.0 \\
\mathrm{Se} & 1226.9\end{array}$ & $\begin{array}{ll}C_{\text {T.I }} & 0.105 \\
\text { Ce.I } & 0.076\end{array}$ \\
\hline $\begin{array}{l}1 \text { 力月 } \\
\text { 総処方 件数 }\end{array}$ & $\begin{array}{c}\mathrm{Z}=-2.82<\mathrm{Z}_{0} \\
\text { 適合 }(5 \%)\end{array}$ & $\begin{array}{c}\mu=21<\mu_{1} \\
\text { 適令 }(1 \%)\end{array}$ & 0.576 & 0.332 & $\begin{array}{l}\mathrm{F}_{\mathrm{R}}=29.82>\mathrm{F} \\
\text { 適合 }(\alpha=0.01)\end{array}$ & $\begin{array}{ll}\text { ST } & 1802.8 \\
\text { Se } & 1486.0\end{array}$ & $\begin{array}{ll}\text { CT.I } & 0.088 \\
\text { Ce.I } & 0.073\end{array}$ \\
\hline $\begin{array}{l}1 \text { 力月 } \\
\text { 外 来 剂 数 }\end{array}$ & $\begin{array}{c}\mathrm{Z}=-6.15<\mathrm{Z}_{0} \\
\text { 適合 }(5 \%)\end{array}$ & $\begin{array}{c}\mu=8<\mu 1 \\
\text { 適令 }(1 \%)\end{array}$ & 0.864 & 0.747 & $\begin{array}{l}\mathrm{F}_{\mathrm{R}}=176.75>\mathrm{F} \\
\text { 適合 }(\alpha=0.01)\end{array}$ & $\begin{array}{l}\text { ST } 22521.0 \\
\text { Se } 11431.7\end{array}$ & $\begin{array}{ll}\text { CT.I } & 0.153 \\
\text { Ce.I } & 0.078\end{array}$ \\
\hline $\begin{array}{l}1 \text { 力月 } \\
\text { 総 剂 数 }\end{array}$ & $\begin{array}{c}\mathrm{Z}=-5.89<\mathrm{Z}_{0} \\
\text { 適合 }(5 \%)\end{array}$ & $\begin{array}{c}\mu=9<\mu 1 \\
\text { 適合 }(1 \%)\end{array}$ & 0.826 & 0.682 & $\begin{array}{l}\mathrm{F}_{\mathrm{R}}=128.73>\mathrm{F} \\
\text { 適合 }(\alpha=0.01)\end{array}$ & $\begin{array}{l}\text { St } 22801.0 \\
\text { Se } 12962.0\end{array}$ & $\begin{array}{ll}\text { CT.I } & 0.131 \\
\text { Ce.I } & 0.074\end{array}$ \\
\hline
\end{tabular}

表 1 -B. 処方せん枚数, 処方件数および剂数に関する時系列解析による回帰式の分散分析わよび回䚻検定

\begin{tabular}{|c|c|c|c|c|c|c|c|}
\hline 解 & 回帰式 & 回 & 式 & 分 & 散 & 表 & 回 帰 検 定 \\
\hline 項 目 & $y=b+a x$ & 変動因 & 平方和 $\mathrm{S}$ & 自由度f & 平均平方 $\mathrm{V}$ & 分散比F $F_{0}$ & $F(1,60 ; 0.01)=7.08$ \\
\hline $\begin{array}{l}1 \text { 日平均 } \\
\text { 外来処方せん枚数 }\end{array}$ & $\begin{array}{r}\mathrm{y}=398.10 \\
+1.581 \mathrm{x}\end{array}$ & $\begin{array}{l}\text { 全体 }(\mathrm{T}) \\
\text { 回㷌 }(\mathrm{R}) \\
\text { 残差 }(\mathrm{e})\end{array}$ & $\begin{array}{r}105530.00 \\
49634.63 \\
55895.37\end{array}$ & $\begin{array}{r}61 \\
1 \\
60\end{array}$ & $\begin{array}{r}1730.00 \\
49634.63 \\
931.59\end{array}$ & 53.28 & $\begin{array}{l}F_{0}=53.28>F \\
\text { 適合 }(\alpha=0.01)\end{array}$ \\
\hline $\begin{array}{l}1 \text { 力月 } \\
\text { 外来処方せん枚数 }\end{array}$ & $\begin{array}{r}y=9971.65 \\
+34.998 x\end{array}$ & $\begin{array}{l}\text { 全体 }(\mathrm{T}) \\
\text { 回㷌 }(\mathrm{R}) \\
\text { 残差 }(\mathrm{e})\end{array}$ & $\begin{array}{l}706.59 \times 10^{5} \\
243.20 \times 10^{5} \\
463.39 \times 10^{5}\end{array}$ & $\begin{array}{r}61 \\
1 \\
60\end{array}$ & $\begin{array}{r}11.58 \times 10^{5} \\
243.20 \times 10^{5} \\
7.23 \times 10^{5} \\
\end{array}$ & 31.49 & $\begin{array}{l}F_{0}=31.49>F \\
\text { 適合 }(\alpha=0.01)\end{array}$ \\
\hline $\begin{array}{l}1 \text { 力月 } \\
\text { 総処方せん枚数 }\end{array}$ & $\begin{array}{r}y=13047.58 \\
+28.788 x\end{array}$ & $\begin{array}{l}\text { 全体 }(\mathrm{T}) \\
\text { 回帰 }(\mathrm{R}) \\
\text { 残差 }(\mathrm{e})\end{array}$ & $\begin{array}{l}845.70 \times 10^{5} \\
164.55 \times 10^{5} \\
681.15 \times 10^{5}\end{array}$ & $\begin{array}{r}61 \\
1 \\
60\end{array}$ & $\begin{array}{r}13.86 \times 10^{5} \\
164.55 \times 10^{5} \\
11.35 \times 10^{5}\end{array}$ & 14.14 & $\begin{array}{l}F_{0}=14.14>F \\
\text { 適合 }(\alpha=0.01)\end{array}$ \\
\hline $\begin{array}{l}1 \text { 力月 } \\
\text { 外来処方件数 }\end{array}$ & $\begin{array}{r}y=14156.84 \\
+66.277 x\end{array}$ & $\begin{array}{l}\text { 全体 }(\mathrm{T}) \\
\text { [四帰 }(\mathrm{R}) \\
\text { 残差 } \\
\text { 差 }(\mathrm{e})\end{array}$ & $\begin{array}{r}177.53 \times 10^{6} \\
87.22 \times 10^{6} \\
90.31 \times 10^{6}\end{array}$ & $\begin{array}{r}61 \\
1 \\
60\end{array}$ & $\begin{array}{r}2.91 \times 10^{6} \\
87.22 \times 10^{6} \\
1.51 \times 10^{6}\end{array}$ & 57.95 & $\begin{array}{l}F_{0}=57.95>F \\
\text { 適合 }(\alpha=0.01)\end{array}$ \\
\hline $\begin{array}{l}1 \text { 力月 } \\
\text { 総処方件数 }\end{array}$ & $\begin{array}{r}y=18635.65 \\
+57.548 x\end{array}$ & $\begin{array}{l}\text { 全体 }(\mathrm{T}) \\
\text { 凹慢 }(\mathrm{R}) \\
\text { 残差 }(\mathrm{e})\end{array}$ & $\begin{array}{r}198.25 \times 10^{6} \\
65.76 \times 10^{6} \\
132.49 \times 10^{6}\end{array}$ & $\begin{array}{r}61 \\
1 \\
60\end{array}$ & $\begin{array}{r}3.25 \times 10^{6} \\
65.76 \times 10^{6} \\
2.21 \times 10^{6}\end{array}$ & 29.78 & $\begin{array}{l}F_{0}=29.78>F \\
\text { 適合 }(\alpha=0.01)\end{array}$ \\
\hline $\begin{array}{l}1 \text { 力月 } \\
\text { 外来 剂 数 }\end{array}$ & $\begin{array}{r}y=112895.47 \\
+1078.569 x\end{array}$ & $\begin{array}{l}\text { 全体 }(\mathrm{T}) \\
\text { 回㷌 }(\mathrm{R}) \\
\text { 残容: }(\mathrm{e})\end{array}$ & $\begin{array}{r}309.39 \times 10^{8} \\
230.98 \times 10^{8} \\
78.41 \times 10^{8} \\
\end{array}$ & $\begin{array}{r}61 \\
1 \\
60\end{array}$ & $\begin{array}{r}5.07 \times 10^{8} \\
230.98 \times 10^{8} \\
1.31 \times 10^{8} \\
\end{array}$ & 176.75 & $\begin{array}{l}F_{0}=176.75>F \\
\text { 適合 }(\alpha=0.01)\end{array}$ \\
\hline $\begin{array}{l}1 \text { 力月 } \\
\text { 総 剂 }\end{array}$ & $\begin{array}{r}y=141903.98 \\
+1043.741 x\end{array}$ & $\begin{array}{l}\text { 全体 }(\mathrm{T}) \\
\text { 回帰 }(\mathrm{R}) \\
\text { 残差 }(\mathrm{e})\end{array}$ & $\begin{array}{l}317.13 \times 10^{8} \\
216.31 \times 10^{8} \\
100.82 \times 10^{8}\end{array}$ & $\begin{array}{r}61 \\
1 \\
60\end{array}$ & \begin{tabular}{r|}
$5.20 \times 10^{8}$ \\
$216.31 \times 10^{8}$ \\
$1.68 \times 10^{8}$ \\
\end{tabular} & 128.73 & $\begin{array}{l}F_{0}=128.73>F \\
\text { 適合 }(\alpha=0.01)\end{array}$ \\
\hline
\end{tabular}


結果

\section{1 、原系列値に関する統計学}

1-1. RUN 検定 (I)

RUN 検定 (I）は 表 1-A のごとく, 1 力月総処方 せん枚数を除いて危険率 $5 \%$ で適合した. 1 力月総処方 せん枚数は $Z=-1.28$ の值となり, RUN 検定は危険 率 $5 \%$ では適合せず xi，yi が互いに独立した関係とな った.

1-2. RUN 検定 (II)

RUN 検定（II）は 表 1-A のごとく，RUN 検定 （I）と同様に，1 力月総処方せん枚数を除いて危険率 $1 \%$ RUN 検定に適合した. 1 力月総処方せん枚数 は $\mu=27$ となり危険率 $5 \%$ で適合しなかった。

\section{1-3. 相関係数 $(\mathrm{r}$ )}

相関係数は表 $1-\mathrm{A}$ のごとく，最小值は 1 力月総処方 せん枚数 $\mathrm{r}=0.44$, 最大值は 1 力月外来剂数 $\mathrm{r}=0.86$ で あった。

1-4. 寄与率 $\left(\mathrm{r}^{2}\right)$

寄与率 $\left(\mathrm{r}^{2}\right)$ は表 1 - $\mathrm{A}$ のように, 最小值は 1 力月総 処方せん枚数 $\mathrm{r}^{2}=0.195$ (19.5\%) であり, 最大值は 1 カ月外来剤数 $\mathrm{r}^{2}=0.747(74.7 \%)$ であった。また， 1 日 平均外来処方せん枚数は $\mathrm{r}^{2}=0.470(47.0 \%)$ であり，
1 カ月外来処方せん枚数 $\mathrm{r}^{2}=0.344(34.4 \%)$ より大き な値となった。

1-5. 相関係数検定

相関係数検定は表 $1-\mathrm{A}$ のごとく， $\alpha=0.01$, 自由度 $\phi_{1}=1, \phi_{2}=60$ の分散比はF 分布表よりもとめると 7.08 となる. 相関係数検定を $\mathrm{F}$ 検定で行ならとすべての項目 が危険率 $1 \%$ で適合した。

1-6. 標準偏差值と変動係数值

標準偏差値と変動係数は表 1-A のごとく, 標準偏差 において回帰分散の残差 偏差（ $\mathrm{S}_{\mathrm{T}}$ ） は全体の標準偏差

$\left(\mathrm{S}_{\ominus}\right)$ より小さな值となった。また，変動係数值におい て 1 力月外来剂数の残差の変動係数 $\mathrm{C}_{\mathrm{eI}}=0.078$ は全体 の変動係数 $\mathrm{C}_{\mathrm{tI}}=0.153$ に比べて $50 \%$ 以下の值となっ た。

1-7. 回帰式の分散分析

回帰式の分散分析表は表 1-B のごとく，分散比 $\mathrm{F}_{0}$ は 最小值が 1 力月総処方せん枚数 $\mathrm{F}_{0}=14.14$, 最大值は 1 カ月外来剤数 $\mathrm{F}_{0}=176.75$ であった. 回帰検定を $\mathrm{F}$ 検 定で行ならと全ての項目が適合した。

1-8. 1 日平均外来処方せん枚数 の回㷌式と $95 \%$ 信 頼区間

1 日平均外来処方せん枚数の回帰式と $95 \%$ 信頼区間

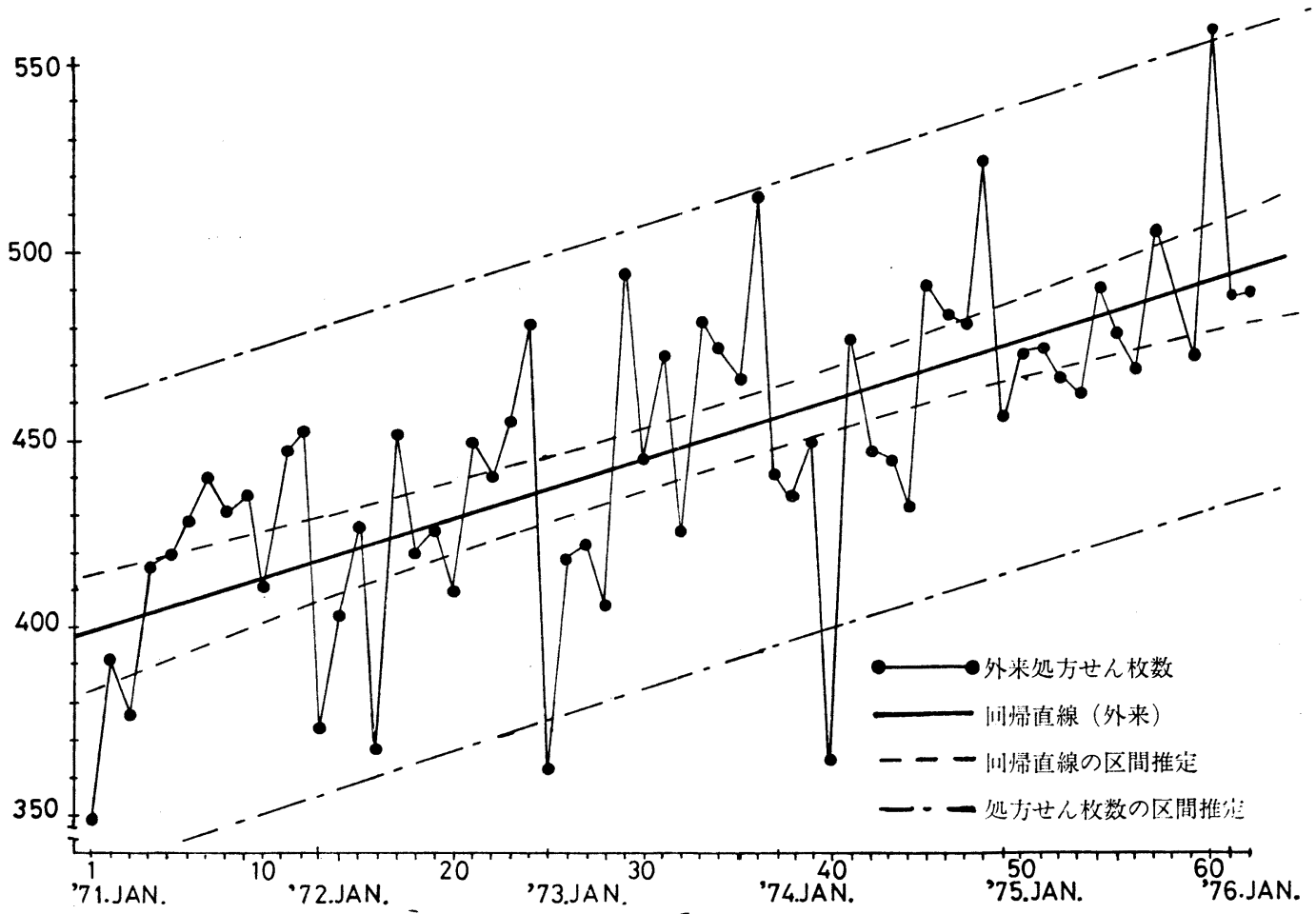

図 1. 1 日平均外来処方せん枚数の回兴直線と区間推定 


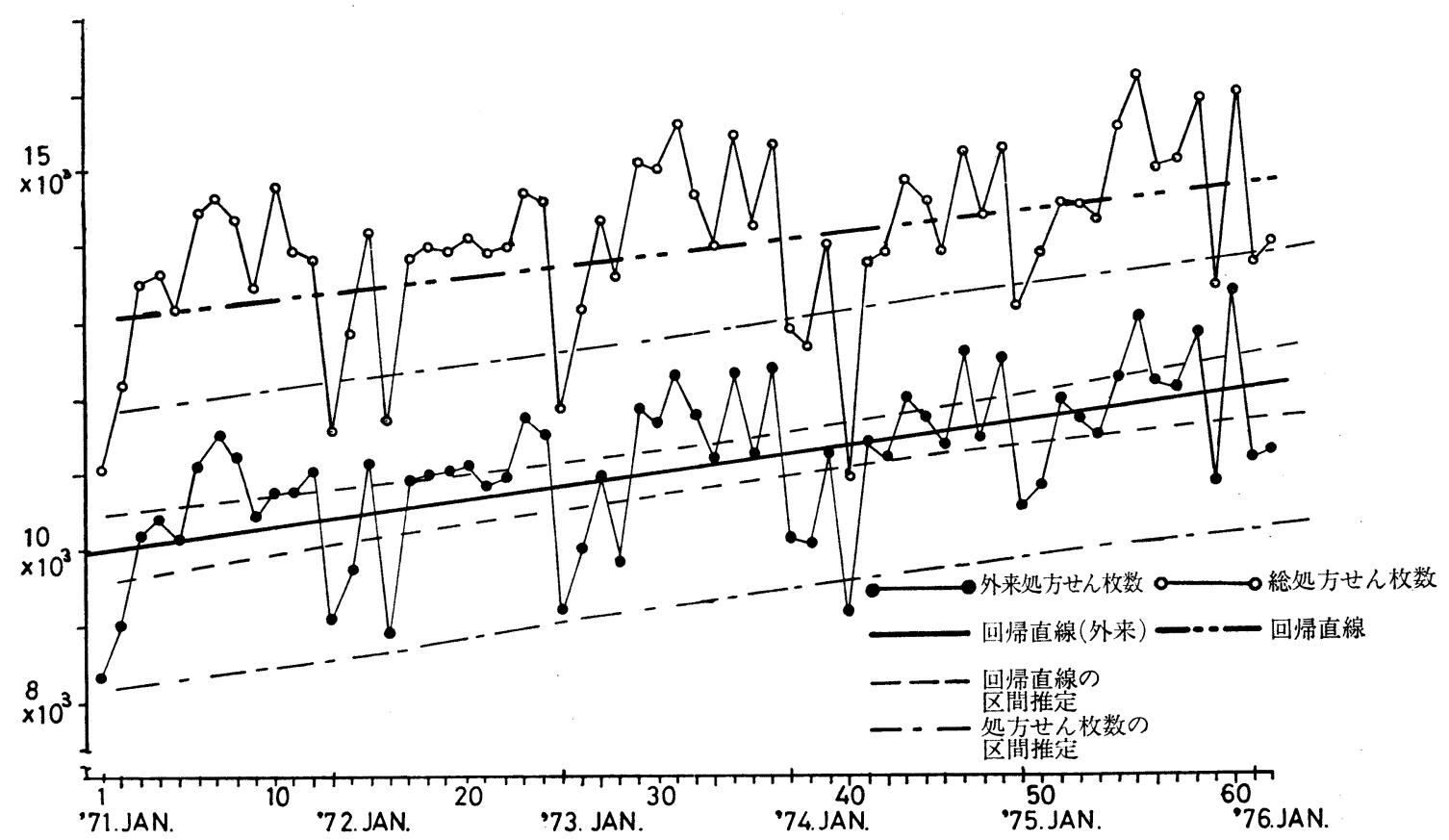

図2.1 1 月月外来処方せん枚数の回帰直線と区間推定および総処方せん枚数の回㷌直線

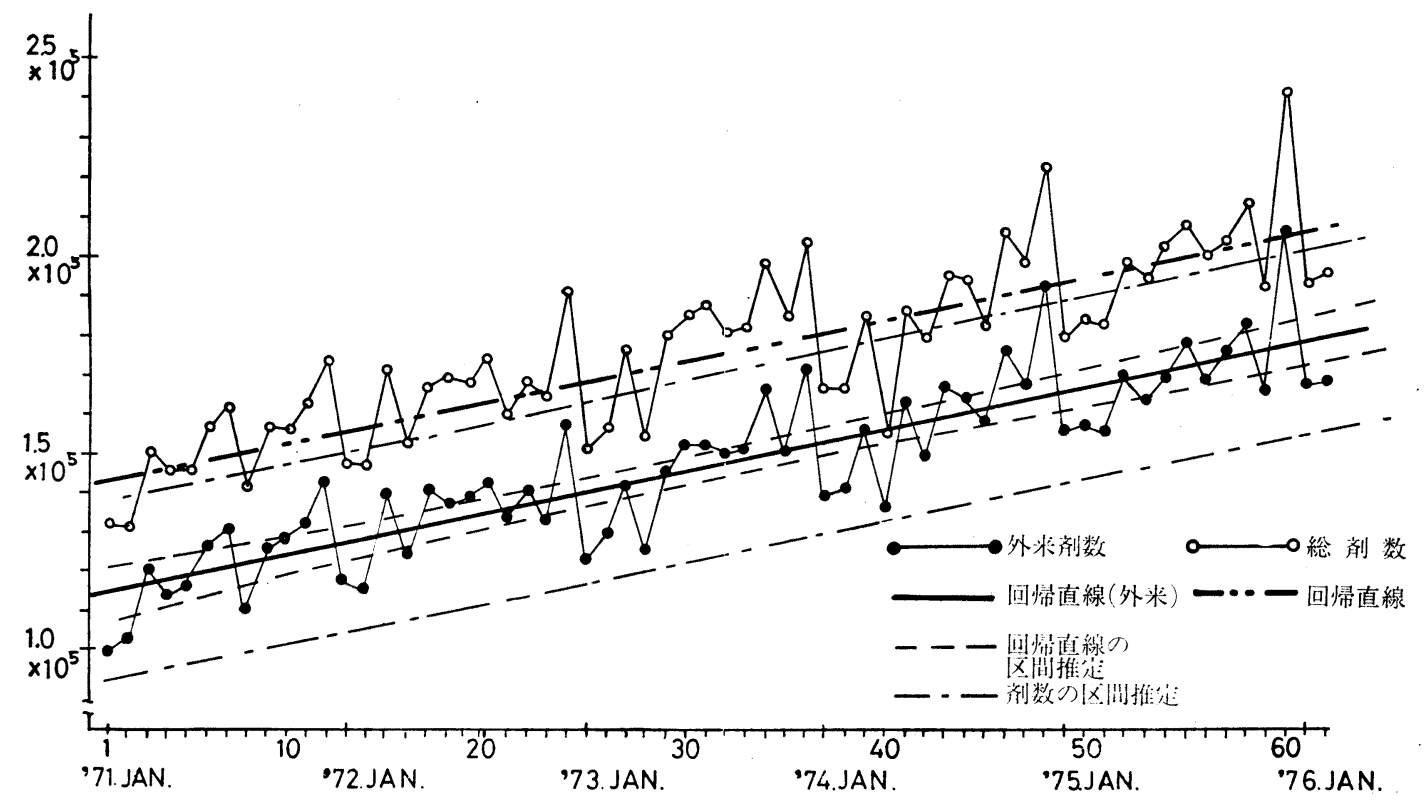

図 3.1 1 力月外来剤数の回㷌直線と区間推定および総剤数の回帰直線

は図 1 のごとく, 62 カ月間の推移は約 98 の増加であ り, 95\% 信頼区間は約 120 の幅があった.

1-9. 1 力月処方せん枚数の回帰式と $95 \%$ 信頼区間

1 力月処方せん枚数の回帰式と $95 \%$ 信頼区間は図 2 のごとく, 62 力月間の推移は外来処方せん枚数は約
2200 の増加であり, 総処方せん枚数は約 1800 の増加で あった. また，外来処方せん枚数の $95 \%$ 信頼区間は約 4000 の幅があった。

1-10. 1 力月剂数の回帰式と $95 \%$ 信頼区間

1 カ月剤数の回帰式と $95 \%$ 信頼区間は図 3 のごと 
表 2-A. 時系列解析による月別変動修正後の処方せん枚数, 処方件数, および斉数に関する 相関係数の検定わよび変動係数值の比較

\begin{tabular}{|c|c|c|c|c|c|c|}
\hline 項 目 & $\begin{array}{c}\text { 相関係数 } \\
(\mathbf{r})\end{array}$ & $\begin{array}{c}\text { 寄与率 } \\
\left(r^{2}\right)\end{array}$ & $\begin{array}{c}\text { 相関係数検定 } \\
\mathrm{F}(1,60 ; 0.01)=7.08\end{array}$ & $\begin{array}{l}\text { 標準偏差 } \\
\mathrm{ST} \quad \mathrm{Se}\end{array}$ & $\begin{array}{c}\text { 変動係数 } \\
\mathrm{C}_{\mathrm{II}}=\mathrm{S} / \overline{\mathrm{x}}\end{array}$ & $\begin{array}{c}\text { 変動係数值比較 } \\
\mathrm{Ce} / \mathrm{CT} \cdot \mathrm{Ce} \cdot \mathrm{I} / \mathrm{Ce} \cdot \mathrm{I}(\%)\end{array}$ \\
\hline $\begin{array}{l}1 \text { 日平均 } \\
\text { 外来処方せん枚数 }\end{array}$ & 0.798 & 0.636 & $\begin{array}{l}\mathrm{F}_{\mathrm{R}}=104.95>\mathrm{F}_{0} \\
\text { 適合 }(\alpha=0.01)\end{array}$ & $\begin{array}{ll}\mathrm{ST} & 33.44 \\
\mathrm{Se} & 20.34\end{array}$ & $\begin{array}{ll}\text { Cт.п } & 0.075 \\
\text { Ce.п } & 0.045\end{array}$ & $\begin{array}{l}\mathrm{Ce} \cdot \mathbb{I} / \mathrm{C}_{\mathrm{T} \cdot \mathrm{II}}=60.00 \\
\mathrm{Ce} \cdot \mathbb{I} / \mathrm{Ce} \cdot \mathrm{I}=66.18\end{array}$ \\
\hline $\begin{array}{l}1 \text { 力月 } \\
\text { 外来処方せん枚数 }\end{array}$ & 0.771 & 0.594 & $\begin{array}{l}F_{R}=87.64>F_{0} \\
\text { 適合 }(\alpha=0.01)\end{array}$ & $\begin{array}{ll}\mathrm{ST} & 781.62 \\
\mathrm{Se} & 502.40\end{array}$ & $\begin{array}{ll}\text { Cт.II } & 0.070 \\
\text { Ce.II } & 0.045\end{array}$ & $\begin{array}{l}\mathrm{Ce} \cdot \mathbb{I} / \mathrm{C}_{\mathrm{T} \cdot \mathrm{II}}=64.29 \\
\mathrm{Ce} \cdot \mathrm{II} / \mathrm{Ce} \cdot \mathrm{I}=56.96\end{array}$ \\
\hline $\begin{array}{l}1 \text { 力月 } \\
\text { 総処方せん枚数 }\end{array}$ & 0.603 & 0.364 & $\begin{array}{l}F_{R}=34.31>F_{0} \\
\text { 適合 }(\alpha=0.01)\end{array}$ & $\begin{array}{ll}\text { ST } & 808.98 \\
\text { Se } & 650.59\end{array}$ & $\begin{array}{ll}\text { CT.II } & 0.058 \\
\text { Ce.II } & 0.047\end{array}$ & $\begin{array}{l}\mathrm{Ce} \cdot \mathbb{I} / \mathrm{C}_{\mathrm{T} \cdot \mathrm{II}}=81.03 \\
\mathrm{Ce} \cdot \mathrm{II} / \mathrm{Ce} \cdot \mathrm{I}=61.84\end{array}$ \\
\hline $\begin{array}{l}1 \text { 力月 } \\
\text { 外来処方件数 }\end{array}$ & 0.856 & 0.733 & $\begin{array}{l}F_{R}=164.86>F_{0} \\
\text { 適合 }(\alpha=0.01)\end{array}$ & $\begin{array}{lr}\text { ST } & 1342.81 \\
\text { Se } & 699.40\end{array}$ & $\begin{array}{ll}\text { C }_{\text {T.II }} & 0.083 \\
\text { Ce.II } & 0.043\end{array}$ & $\begin{array}{l}\mathrm{Ce} \cdot \mathrm{I} / \mathrm{C}_{\mathrm{T} \cdot \mathrm{I}}=51.81 \\
\mathrm{Ce} \cdot \mathrm{I} / \mathrm{Ce} \cdot \mathrm{I}=56.58\end{array}$ \\
\hline $\begin{array}{l}1 \text { 力月 } \\
\text { 総処方件数 }\end{array}$ & 0.722 & 0.521 & $\begin{array}{l}F_{R}=65.33>F_{0} \\
\text { 適合 }(\alpha=0.01)\end{array}$ & $\begin{array}{lr}\mathrm{S}_{\mathrm{T}} & 1361.44 \\
\mathrm{Se} & 949.80\end{array}$ & $\begin{array}{ll}\text { Cт.II } & 0.067 \\
\text { Ce.II } & 0.046\end{array}$ & $\begin{array}{l}\mathrm{Ce} \cdot \mathrm{II} / \mathrm{C} \cdot \mathrm{T} \cdot \mathrm{I}=68.66 \\
\mathrm{Ce} \cdot \mathrm{II} / \mathrm{Ce} \cdot \mathrm{I}=63.01\end{array}$ \\
\hline $\begin{array}{l}1 \text { 力月 } \\
\text { 外 来 剂 数 }\end{array}$ & 0.956 & 0.913 & $\begin{array}{l}\mathrm{F}_{\mathrm{R}}=629.67>\mathrm{F}_{0} \\
\text { 適合 }(\alpha=0.01)\end{array}$ & $\begin{array}{l}\text { ST } 19910.62 \\
\text { Se } \cdot 5921.46\end{array}$ & $\begin{array}{ll}\text { Cт.II } & 0.135 \\
\text { Ce.II } & 0.040\end{array}$ & $\begin{array}{l}\mathrm{Ce} \cdot \mathrm{II} / \mathrm{CT}_{\mathrm{T} \cdot \mathrm{II}}=29.63 \\
\mathrm{Ce} \cdot \mathrm{II} / \mathrm{Ce} \cdot \mathrm{I}=51.28\end{array}$ \\
\hline $\begin{array}{l}1 \text { 力月 } \\
\text { 総．剂 }\end{array}$ & 0.938 & 0.880 & $\begin{array}{l}F_{R}=438.70>F_{0} \\
\text { 適合 }(\alpha=0.01)\end{array}$ & $\begin{array}{lr}S_{T} & 19465.52 \\
\text { Se } & 6807.89\end{array}$ & $\begin{array}{ll}\text { Cт.II } & 0.111 \\
\text { Ce.II } & 0.039\end{array}$ & $\begin{array}{l}\mathrm{Ce} \cdot \mathrm{II} / \mathrm{C}_{\mathrm{T} \cdot \mathrm{II}}=35.14 \\
\mathrm{Ce} \cdot \mathrm{II} / \mathrm{Ce} \cdot \mathrm{I}=52.70\end{array}$ \\
\hline
\end{tabular}

表 $2-\mathrm{B}$. 月别変動修正後の処方せん枚数，処方件数，および剂数に関する 時系列解析による回帰式の分散分析および回㷌検定

\begin{tabular}{|c|c|c|c|c|c|c|c|}
\hline 解 & 回帰式 & 回 & 式 & 分 & 散 & 表 & 回 帰 検 定 \\
\hline 項 目 & $y=b+a x$ & 変動因 & 平方和 S & 自由度f & 平均平方 $\mathrm{V}$ & 分散比F 0 & $F(1,60 ; 0.01)=7.08$ \\
\hline $\begin{array}{l}1 \text { 日平均 } \\
\text { 外来処方せん枚数 }\end{array}$ & $\begin{array}{r}y=401.94 \\
+1.479 x\end{array}$ & $\begin{array}{l}\text { 全体 }(\mathrm{T}) \\
\text { 回㷌 }(\mathrm{R}) \\
\text { 残差 }(\mathrm{e})\end{array}$ & $\begin{array}{l}68229.49 \\
43411.19 \\
24818.30 \\
\end{array}$ & $\begin{array}{r}61 \\
1 \\
60 \\
\end{array}$ & $\begin{array}{r}1118.52 \\
43411.19 \\
431.64 \\
\end{array}$ & 104.95 & $\begin{array}{l}\mathrm{F}_{0}=104.95>\mathrm{F} \\
\text { 適合 }(\alpha=0.01)\end{array}$ \\
\hline $\begin{array}{l}1 \text { 力月 } \\
\text { 外来処方せん枚数 }\end{array}$ & $\begin{array}{r}y=10052.81 \\
+33.379 x\end{array}$ & $\begin{array}{l}\text { 全体 }(\mathrm{T}) \\
\text { 回帰 }(\mathrm{R}) \\
\text { 残差 }(\mathrm{e})\end{array}$ & $\begin{array}{l}372.66 \times 10^{5} \\
221.22 \times 10^{5} \\
151.44 \times 10^{5}\end{array}$ & $\begin{array}{r}61 \\
1 \\
60\end{array}$ & $\begin{array}{r}6.11 \times 10^{5} \\
221.22 \times 10^{5} \\
2.52 \times 10^{5}\end{array}$ & 87.65 & $\begin{array}{l}F_{0}=87.65>F \\
\text { 適合 }(\alpha=0.01)\end{array}$ \\
\hline $\begin{array}{l}1 \text { 力月 } \\
\text { 総処方せん枚数 }\end{array}$ & $\begin{array}{r}y=13123.26 \\
+27.047 x\end{array}$ & $\begin{array}{l}\text { 全体 }(\mathrm{T}) \\
\text { 回㷌 }(\mathrm{R}) \\
\text { 残差 }(\mathrm{e})\end{array}$ & $\begin{array}{l}399.21 \times 10^{5} \\
145.25 \times 10^{5} \\
253.96 \times 10^{5}\end{array}$ & $\begin{array}{r}61 \\
1 \\
60\end{array}$ & $\begin{array}{r}6.54 \times 10^{5} \\
145.25 \times 10^{5} \\
4.23 \times 10^{5}\end{array}$ & 34.32 & $\begin{array}{l}F_{0}=34.32>F \\
\text { 適合 }(\alpha=0.01)\end{array}$ \\
\hline $\begin{array}{l}1 \text { 力月 } \\
\text { 外来処方件数 }\end{array}$ & $\begin{array}{r}y=14267.78 \\
+63.729 x\end{array}$ & $\begin{array}{l}\text { 全体 }(\mathrm{T}) \\
\text { 回㷌 }(\mathrm{R}) \\
\text { 残差 }(\mathbf{e})\end{array}$ & $\begin{array}{r}109.99 \times 10^{6} \\
80.64 \times 10^{6} \\
29.35 \times 10^{6} \\
\end{array}$ & $\begin{array}{r}61 \\
1 \\
60\end{array}$ & $\begin{array}{r}1.80 \times 10^{6} \\
80.64 \times 10^{6} \\
0.49 \times 10^{6}\end{array}$ & 164.86 & $\begin{array}{l}F_{0}=164.86>F \\
\text { 適合 }(\alpha=0.01)\end{array}$ \\
\hline $\begin{array}{l}1 \text { 力月 } \\
\text { 総処方件数 }\end{array}$ & $\begin{array}{r}y=18818.29 \\
+54.482 x\end{array}$ & $\begin{array}{l}\text { 全体 }(\mathrm{T}) \\
\text { 回㷌 }(\mathrm{R}) \\
\text { 残差 }(\mathrm{e})\end{array}$ & $\begin{array}{r}113.07 \times 10^{6} \\
58.94 \times 10^{6} \\
54.13 \times 10^{6} \\
\end{array}$ & $\begin{array}{r}61 \\
1 \\
60 \\
\end{array}$ & $\begin{array}{r}1.85 \times 10^{6} \\
58.94 \times 10^{6} \\
0.92 \times 10^{6}\end{array}$ & 65.33 & $\begin{array}{l}F_{0}=65.33>F \\
\text { 適合 }(\alpha=0.01)\end{array}$ \\
\hline $\begin{array}{l}1 \text { 力月 } \\
\text { 外 来 剂 数 }\end{array}$ & $\begin{array}{r}y=114360.28 \\
+1054.497 x\end{array}$ & $\begin{array}{l}\text { 全体 }(\mathrm{T}) \\
\text { 回㷌 }(\mathrm{R}) \\
\text { 残差 }(\mathrm{e})\end{array}$ & $\begin{array}{r}241.82 \times 10^{8} \\
220.79 \times 10^{8} \\
21.04 \times 10^{8}\end{array}$ & $\begin{array}{r}61 \\
1 \\
60\end{array}$ & $\begin{array}{r}3.96 \times 10^{8} \\
220.79 \times 10^{8} \\
0.35 \times 10^{8}\end{array}$ & 629.67 & $\begin{array}{l}F_{0}=629.67>F \\
\text { 適合 }(\alpha=0.01)\end{array}$ \\
\hline $\begin{array}{l}1 \text { カ月 } \\
\text { 総 绪 }\end{array}$ & $\begin{array}{r}y=143128.01 \\
+1011.939 x\end{array}$ & $\begin{array}{l}\text { 全体 }(\mathrm{T}) \\
\text { 回㷌 }(\mathrm{R}) \\
\text { 残差 }(\mathrm{e})\end{array}$ & \begin{tabular}{|r|}
$231.13 \times 10^{8}$ \\
$203.33 \times 10^{8}$ \\
$27.81 \times 10^{8}$ \\
\end{tabular} & $\begin{array}{r}61 \\
1 \\
60\end{array}$ & $\begin{array}{r}3.79 \times 10^{8} \\
203.33 \times 10^{8} \\
0.46 \times 10^{8}\end{array}$ & 438.70 & $\begin{array}{l}F_{0}=438.70>F \\
\text { 適合 }(\alpha=0.01)\end{array}$ \\
\hline
\end{tabular}


く, 62 力月間の推移は外来剂数で約 65000 , 総剤数で 約 62000 の增加であった。 また，区間推定の $95 \%$ 信 頼区間は約 43000 であり，グラフに書いてみると信頼 区間関して外来剂数が最も幅が狭くなった。なお，総 処方せん枚数，および総剂数の区間推定はグラフに記入 していないまた，処方件数のグラフは本報で記裁しな かった.

\section{2. 月别変動悠正值に関する統計学的解析}

\section{2-1. 相関係数 $(r)$}

相関係数 $(\mathrm{r})$ は表 2-A のごとく, 最小值は 1 カ月 総処方せん枚数の $\mathrm{r}=0.603$ であり, 最大值は 1 力月外 来剂数の $\mathrm{r}=0.956$ であった.

\section{2-2. 寄与率 $\left(\mathrm{r}^{2}\right)$}

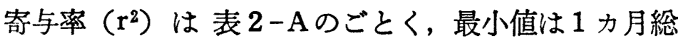
処方せん枚数の $\mathrm{r}^{2}=0.364(36.4 \%)$ であり，1 力月総処 方せん枚数以外はすへて寄与率 $50 \%$ 以上であった．最 大值は 1 力月外来剂数 $\mathrm{r}^{2}=0.913(91.3 \%)$ であった. 原 系列値（表 1-A）に比へ，最小値は 0.364 に対して原系 列值の 0.195 , 最大值は 0.913 に対して 0.747 であっ た.

\section{2-3. 相関俰数検定}

$\alpha=0.01$, 自由度 $\phi_{1}=1 ， \phi_{2}=60$ の分散比は F 分布 表よりもとめると 7.08 となる. 相関係数検定を F検定 で行ならとすべての項目が危険率 $1 \%$ で適合した。

\section{2-4. 標準偏差, 変動係数値の比較}

標準偏差と变動係数值は表 2-A のごとく, 変動係数 值の比較は最大值が 1 力月外来㓮数であり, 回帰分散の 残差の変動係数 $\mathrm{Ce}_{\mathrm{II}}=0.040$ に対して全体の変動係 数 $\mathrm{C}_{\text {TII }}=0.135,29.6 \%$ であった．最小は 1 カ月総処方せん 枚数の残差变動係数 $\mathrm{C}_{\mathrm{eII}}=0.058$ に対して全体の变動係 数 $\mathrm{C}_{\text {TII }}=0.047$ で $81.03 \%$ であった. 原系列值 $\mathrm{Ce}_{\mathrm{I}}$ （表 1-A） と月別変動修正 值 $\mathrm{Ce}_{\mathrm{II}}$ の残差の変動係数 の比較では最小值は 1 力月外来剂数の $\mathrm{Ce}_{\mathrm{II}} / \mathrm{Ce}_{\mathrm{I}} \times 100$ $=51.28$, 最大值は 1 日平均外来処方せ几 枚数の 66.18 であり，月別変動值を補正した場合に変動係数は $50 \%$ 以上減少した.

\section{2-5. 回㱕式の分散分析}

回㷌式の分散分析は 表 2-B のごとく, 分散比 $\mathrm{F}_{0}$ の 最小は 1 力月 総処方せん枚数 34.32 であり, 最大は 1 力月外来剤数 629.67 であった. 回帰検定を $\mathrm{F}$ 検定で行 ならと危険率 $1 \%$ \%すべての項目が適合した。分散比を 原系列値（表 1-B）と比較すると，最小值の 34.32 に対して原系列值の 14.14 , 最大值の 629.67 に対して 176.75 であり，月別変動修正データの分散比の大きい 增加となった。
2-6．1 日平均外来処方せ几枚数の回帰式と $95 \%$ 信頼区間

1 日平均外来処方せ几枚数の月別変動修正值の回帰式 と $95 \%$ 信頼区間は図 4 のごとく, 62 力月間の推移は約 92 の增加であり, 原系列值（図 1) の 98 と比べ大きな 相違ではなかった．区間推定の 95\% 信頼区間は約 85 で あり，原系列值の 120 よりかなり減少を示した．回帰 式またデータの信頼区間の幅は原系列値に対して相当 の減少を示した

2-7. 1 日平均外来処方せ几枚数の原系列値 と月別 変動修正值の残差比較

1 日平均外来処方せ几枚数の原系列値と月別変動修正 値の残差比較は図 5 のごとく, 月別変動修正值の残差偏 差は原系列値に比較して 1972 年頃の動向は小さく, 1973 年〜 1974 年にかけてほぼ同様な動向を示し，1975 年では原系列値の残差の動向は小さくなった。

2-8. 1 力月処方せん枚数の回㷌式と $95 \%$ 信頼区間

1 力月処方せ几枚数の回帰式と $95 \%$ 信頼区間は図 6 のごとく，区間推定の 95\% 信頼区間は約 2000 で原系 列值（因 2) の 4000 に対して $50 \%$ の減少を示した.

2-9. 1 力月剤数の回㷌式と $95 \%$ 信頼区間

1 ケ月剂数の回帰式と $95 \%$ 信頼区間は図 7 のごと く, 区間推定の $95 \%$ 信頼区間は約 25000 であり, 原系 列値（図 3) の 43000 と比較して $45 \%$ 以上の減少であ った. 62 力月間の推移では約 63000 の增加であり, 原 系列値の 65000 に対して余り相違がみられなかった.

\section{考客}

RUN 検定に打壮る RUN 検定（II）は $\alpha=0.01$, $\alpha=0.05$ の 2 つ検定が行ならことができ,計算法も簡 便で時系列解析での予知的相関関係をしらべるには有用 な手法であると考学られる．RUN 検定の危険率 $5 \%$ で 適合しなかった 1 力月総処方せん枚数は，その他の統計 学的解析法に执いてもあまり良い結果を示さず，時系列 解析を行ならためには良いデータとはいえないと思われ る.

寄与率は xi が yi におよぼしている影響の度合を示し ているが，寄与率 $50 \%\left(\mathrm{r}^{2}=0.500\right)$ 以上必要であると 考えた場合に，原系列データでは剤数の項目だけであっ た. 月別变動修正值では 1 力月総処方せん枚数を除いて はすべて寄与率 $50 \%$ 以上あり，時系列解析を行なうの に月別変動修正值は十分な值を示していると考えられ る.

変動係数の原系列值と月別变動修正值の比較では, 最 小值は 1 力月外来剂数の 29.63 , 最大值は 1 力月総処方 せん枚数の 81.03 であり，総処方せん枚数では月別变 


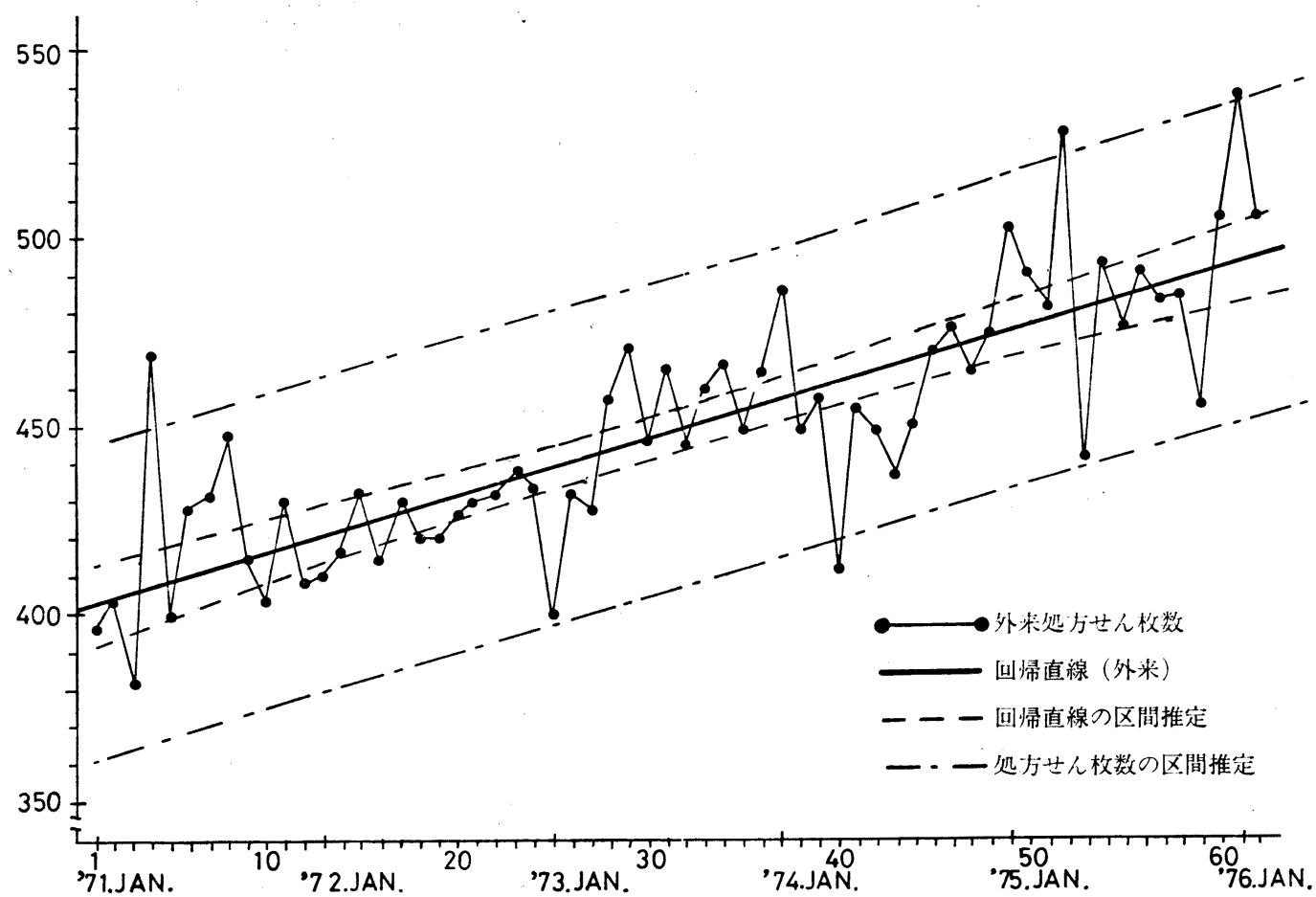

図 4.月別変動修正後の 1 日平均外来処方せん枚数の回帰直線と区間推定

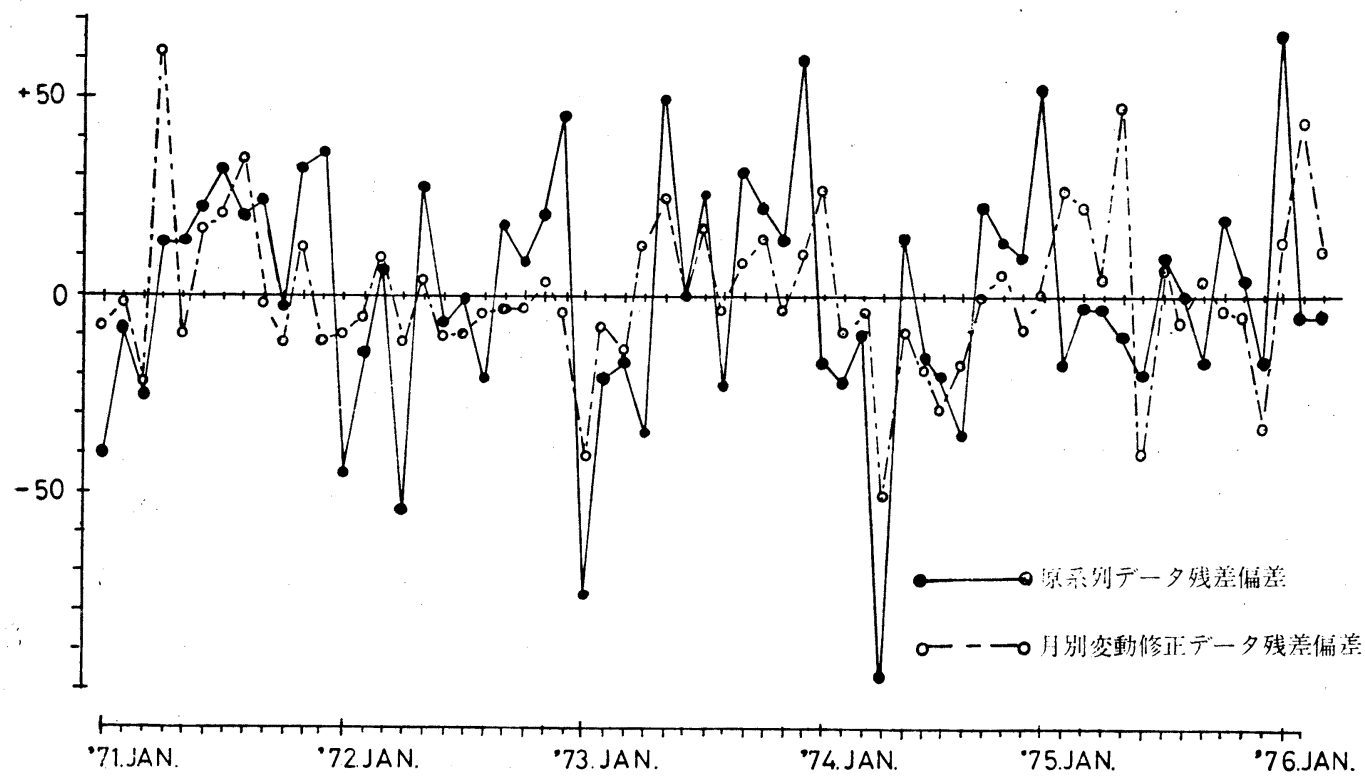

図 5.1 日平均外来処方せん枚数での原系列データと月別変動修正データでの残差の比較

変動指数で補正しても変動係数の減少とはならず，月別 変動の影響は小さいと考えられる.

回帰式の 62 力月間の推移において, 原系列値と月別 変動修正值では大きな相違はなかったが，95\% 信頼区
間は月別変動修正值では減少し調剂業務量の予測に十分 利用し得ると思われる。

データの回帰式に対する影響は, 項目別で 1 力月総処 方せん枚数, 1 力月総処方件数, 1 力月外来処方せん枚 


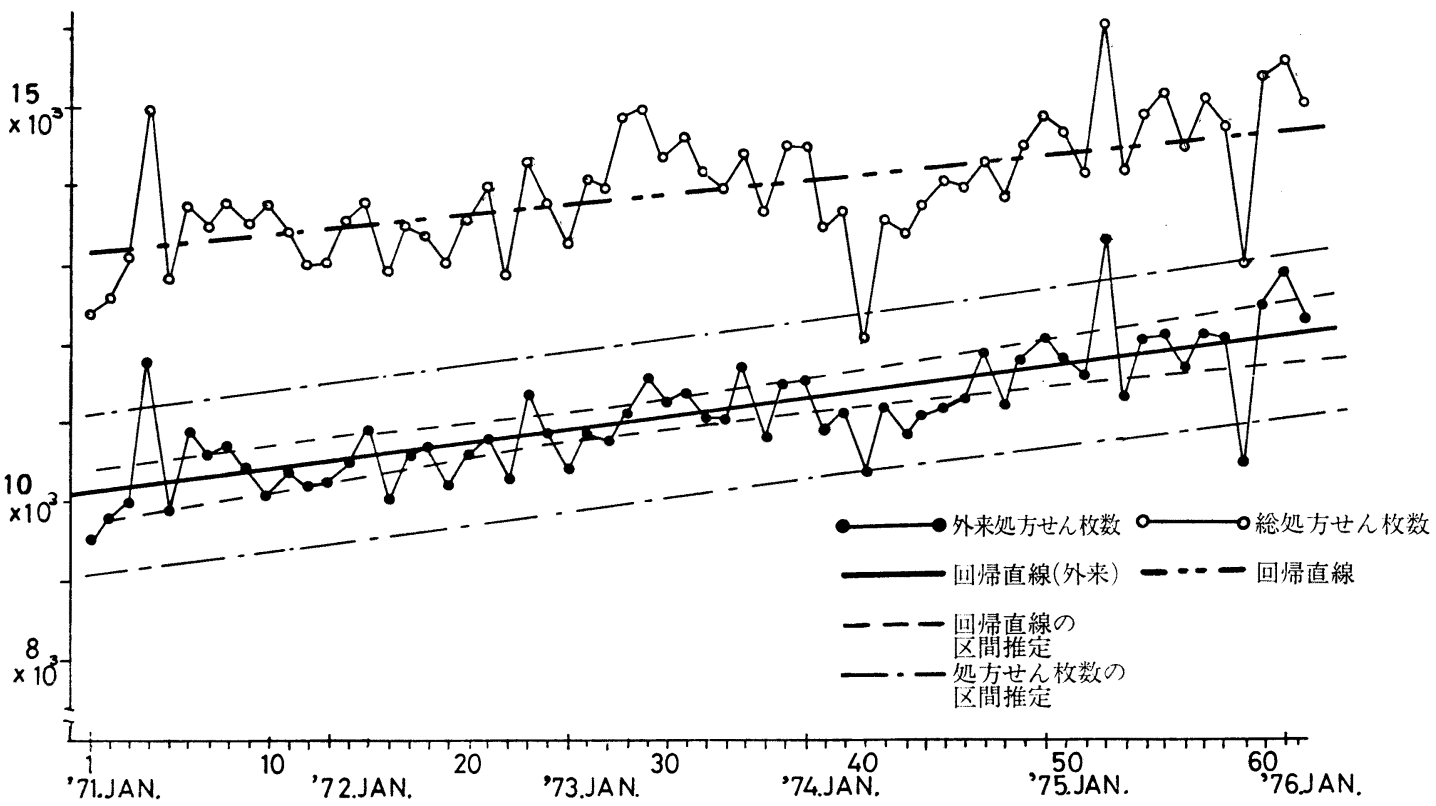

図 6. 月別変動修正後の 1 力月外来処方せ几枚数の回㷌直線と区間推定および総処方せん枚数の回帰直線

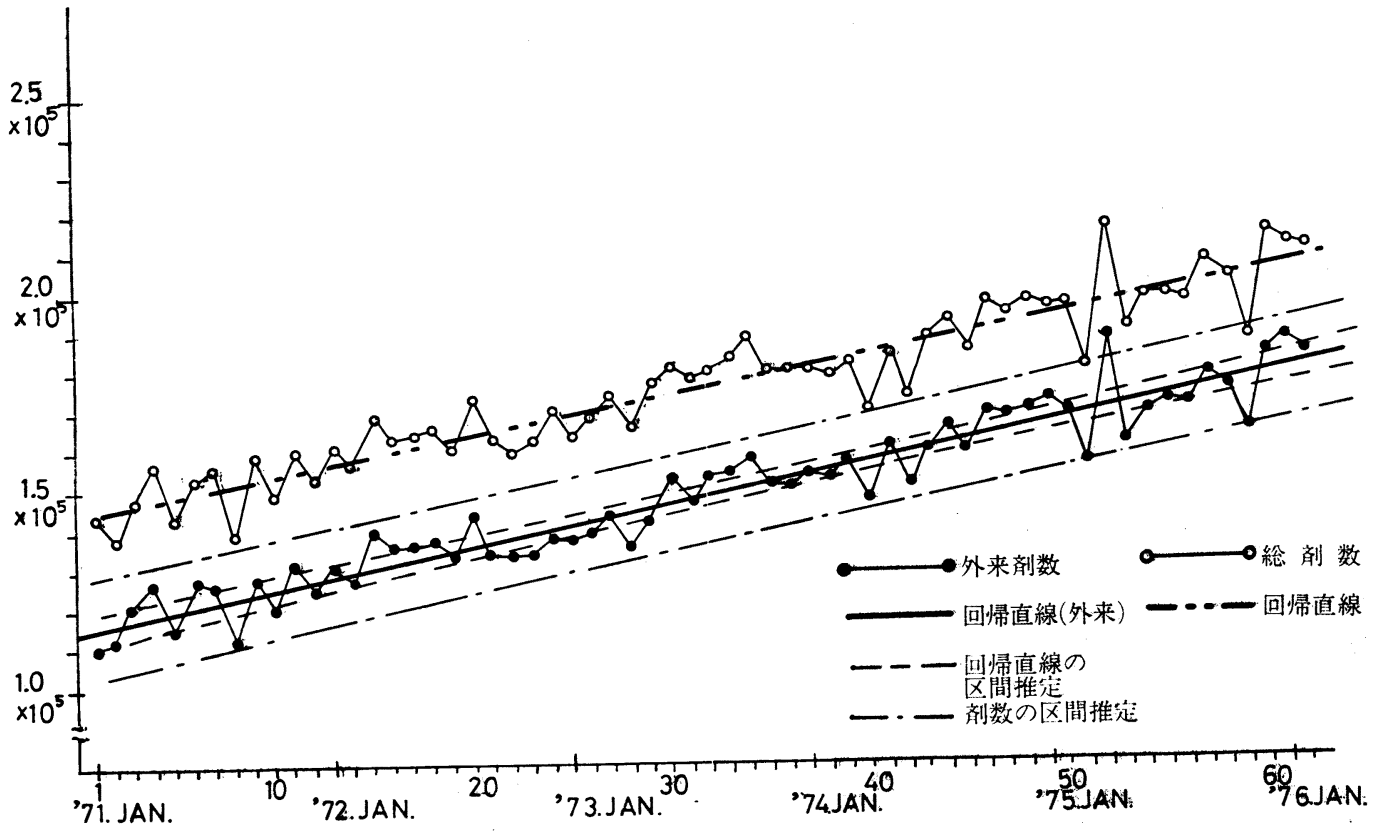

図 7. 月別変動正後の 1 力月外来剂数の回帰直線と区間推定おょび総剤数の回帰直線

数，1 日平均外来処方世ん枚数，1力用外来処方件数,

1 力月総剂数, 1 力月外来剂数の順に影慜する度合恃太

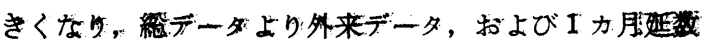

より厢日変動を除去した 1 日平均数である. 従って 1 日
平均外来数として時系列解析を行なった場合に総して良 い緒果が得られると思われる. 最後に, 今後数年間の調

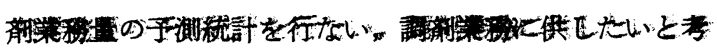
えている. 


$$
\text { 文献 }
$$

1）斉藤 弥, 宮家 㳯, 岩崎由雄 : 調剂業務の管理 学的検討 (第 1 報), 病院薬学, 2, 232 (1977).

2) P.G. ホーエル : 初等統計学, 培風館 (1970).

3）益山元三郎監修：統計計算ポケットプック，日本 規格協会 (1976).

4）実務教育研究所: 現代統計実務講座, II, 実務教 育研究所 (1974).
5）松島庚夫, 江副 力： OR手法とその応用, オ一 么社 (1976).

6) 小林龍一：相関 - 回帰分析法入門, 日科技連 (1975).

7) 竹内 清: 需要予測入門, 丸善 (1974).

8) I. C. I. MONOGRAPH, 2 : 短期予测方式, 培 風館 (1972).

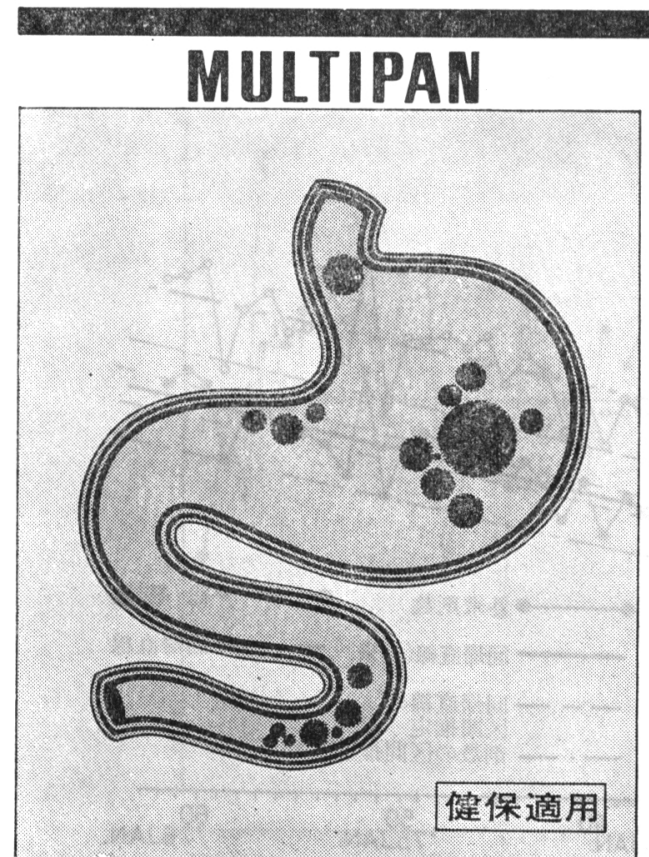

高単位総合活性消化酵素製剤
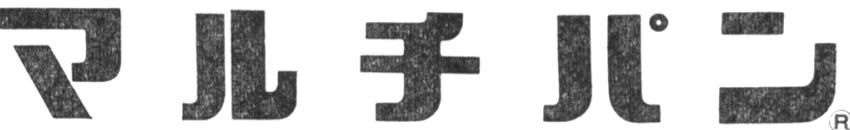

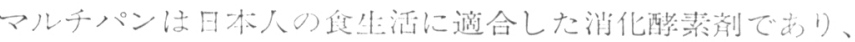

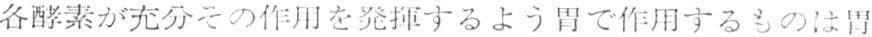
溶顆䊀とし、胑で作用子るきのはエンテリックコーティング を施した腸溶顆粒として㴶剂化しています。

四成分・分量 $(1$ 鉈中 $)$

胃溶顆粒

サンプローゼM……1 $100.0 \mathrm{mg}$

アミロリシン……....... $6.7 \mathrm{mg}$

パンセラーゼ……..... $30.0 \mathrm{mg}$

オリパーゼ $2 \mathrm{~S} \cdots \cdots \cdots \cdots \cdots \cdots \cdots \cdot 60.0 \mathrm{mg}$

\section{腸溶顆粒}

プロテオリクィファーゼ‥ $20.0 \mathrm{mg}$ 日局パンクレアチン……120.0mg
四適庶症

消化不店、過食時の消化促進、消 化不良性下痢、各種聅患による消 化機能障害、手術後の消化力娍迟。

\section{用法・用量}

1 回 1 鉸、1日3回、金事归また洨 全直後、啮まずに経口投与しま守。 重症の場合は適宜增量します。

四包装 1,000 錠 5,000 錠 